\title{
Role of magnesium and minor zirconium on the wear behavior of $5 X X X$ series aluminum alloys under different environments
}

Mohammad Salim KAISER, Mohammad AbduI MATIN, Kazi Mohammad SHOROWORDI

DOI: 10.30464/jmee.2020.4.3.209

Cite this article as:

Kaiser Md S., Matin Md A., Shorowordi K. Md. Role of magnesium and minor zirconium on the wear behavior of 5XXX series aluminum alloys under different environments. Journal of Mechanical and Energy Engineering, Vol. 4(44), No. 3, 2020, pp. 209-220.

\section{VOLUME 4(44) | NO. 3 | SEPTEMBER 2020} ISSN 2544-0780 | e-1SSN 2544-1671

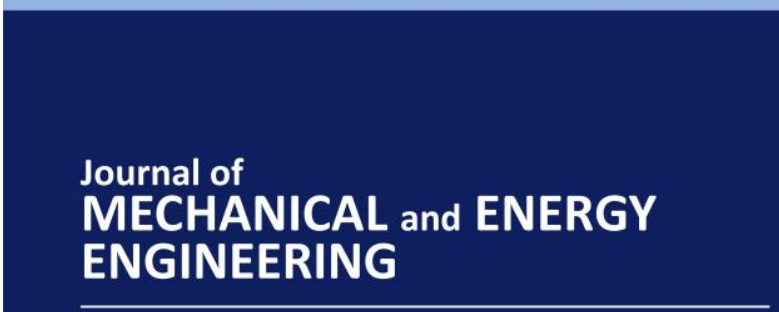

\section{Editor-in-Chief}

Waldemar Kuczyński

Editors

Wojciech Kapłonek | Krzysztof Nadolny
Journal of Mechanical and Energy

Engineering

Website: jmee.tu.koszalin.pl

ISSN (Print): 2544-0780

ISSN (Online): 2544-1671

Volume: $4(44)$

Number: 3

Year: 2020

Pages: 209-220

Article Info:

Received 5 August 2020

Accepted 20 August 2020

\section{Open Access}

This article is distributed under the terms of the Creative Commons Attribution 4.0 (CC BY 4.0) International License (http://creativecommons.org/licenses/by/4.0/), which permits unrestricted use, distribution, and reproduction in any medium, provided you give appropriate credit to the original author(s) and the source, provide a link to the Creative Commons license, and indicate if changes were made. 


\title{
ROLE OF MAGNESIUM AND MINOR ZIRCONIUM ON THE WEAR BEHAVIOR OF 5XXX SERIES ALUMINUM ALLOYS UNDER DIFFERENT ENVIRONMENTS
}

\author{
Mohammad Salim KAISER $^{1 *}$, Mohammad Abdul MATIN ${ }^{2}$, Kazi Mohammad SHOROWORDI $^{3}$ \\ ${ }^{1 *}$ Directorate of Advisory, Extension and Research Services, Bangladesh University of Engineering and \\ Technology, Dhaka-1000, Bangladesh, e-mail: mskaise@ iat.buet.ac.bd \\ ${ }^{2}$ Department of Glass and Ceramic Engineering, Bangladesh University of Engineering and Technology, \\ Dhaka-1000, Bangladesh \\ ${ }^{3}$ Department of Materials and Metallurgical Engineering, Bangladesh University of Engineering and \\ Technology, Dhaka-1000, Bangladesh
}

(Received 5 August 2020, Accepted 20 August 2020)

\begin{abstract}
The tribological performance of 5xxx series aluminum alloys with ternary zirconium is evaluated at ambient conditions under dry, wet and saline environment. The experiment has been done using a Pin-on-Disk apparatus under an applied load of $20 \mathrm{~N}$. The sliding distances varies ranging from $116 \mathrm{~m}-2772 \mathrm{~m}$ at a sliding velocity of $0.385 \mathrm{~ms}^{-1}$. The results show that presence of $\mathrm{Mg}$ and $\mathrm{Zr}$ into this alloy helps to increase their strength and wear resistance under dry sliding condition. But they significantly suffer under wet and corrosive environment due to formation of $\beta$-phase $\mathrm{Al}_{3} \mathrm{Mg}_{2}$, to slip bands and grain boundaries which may lead to and stress-corrosion cracking. The variation of friction coefficient is observed in wet and corrosive environment due to the formation of oxidation film, lubrication, and corrosion action in solution. The SEM analysis shows that brittle $\mathrm{Al}_{3} \mathrm{Mg}_{2}$ phase initiate the fracture surface for $\mathrm{Al}-\mathrm{Mg}$ alloy and $\mathrm{Zr}$ addition accelerate the brittleness of the alloy owing the fine precipitates of $\mathrm{Al}_{3} \mathrm{Zr}$.
\end{abstract}

Keywords: aluminum alloys, environment, wear, corrosion, friction, microstructure

\section{INTRODUCTION}

Pure aluminum is soft, ductile, corrosion resistant and has a high electrical conductivity $[1,2]$. It is widely used for foil and conductor cables, but alloying with other elements is necessary to obtain the higher strengths needed for other applications. Aluminum is most commonly alloyed with copper, zinc, magnesium, silicon, manganese and lithium. Small additions of chromium, titanium, zirconium, scandium, lead, bismuth and nickel are also made and iron is invariably present in small quantities [3-5].The addition of magnesium to aluminum increases the strength through solid solution strengthening and improves their strain hardening ability. These alloys are the highest strength non-heat-treatable aluminum alloys [6-8]. Al-Mg casting alloys have a wide range of application, especially in the automotive and ship borne industry that is directly related to their good mechanical properties $[9,10]$. These alloys are characterized by relatively good castability and are distinguished by excellent corrosion resistance due to high magnesium content $[11,12]$. The alloys may exhibit some instability in properties, which is manifested in two ways. If the magnesium content exceeds 3 to $4 \mathrm{wt} \%$, there is a tendency for the formation $\beta$-phase $\mathrm{Al}_{3} \mathrm{Mg}_{2}$, to precipitate in slip bands and grain boundaries which may lead to intergranular attack and stress-corrosion cracking in corrosive conditions [3, 13]. Precipitation of $\beta$ occurs only slowly at ambient temperatures but is accelerated if the alloys are in a heavily worked condition, or if the temperature is raised. Small additions of $\mathrm{Zr}, \mathrm{Ti}, \mathrm{Sc}$ raise the recrystallisation temperatures, also increase tensile properties for given magnesium content [14-16]. Zirconium is added to aluminum alloys for altering recrystallization behavior, enhancing mechanical properties and thermal stability while retaining electrical conductivity and controlling 
the grain size during solidification. In the first two cases, super saturation of the Al solid solution is achieved during solidification and the metastable $\mathrm{Al}_{3} \mathrm{Zr}$ phase precipitates during annealing and pinning dislocations and subgrain boundaries. In the last case, primary crystals of the equilibrium $\mathrm{Al}_{3} \mathrm{Zr}$ phase act as nucleating substrates for Al grains [17, 18].

Most recent, the Al-Mg alloy has been extensively used in modern structural and functional applications. Proper reinforcement increases the wear properties of the alloys. There is currently no work available which has studied the wear behavior of $\mathrm{Al}-\mathrm{Mg}$ alloy at different environment. The purpose of this study is thus to investigate and report on the combined effect of $\mathrm{Mg}$ and $\mathrm{Zr}$ on the wear behavior of commercially pure aluminum in dry, wet and corrosive environment.

\section{EXPERIMENTAL PROCEDURE}

The materials used in the present study were commercially pure $\mathrm{Al}, 5 \mathrm{xxx}$ series $\mathrm{Al}-\mathrm{Mg}$ alloy and $\mathrm{Zr}$ added 5xxx series Al-Mg-Zr alloy. These alloys were prepared using pure aluminum ingot (99.7\%), industrial pure magnesium $(99.9 \%)$ and master alloys of $\mathrm{Al}-10 \% \mathrm{Zr}$. Melting was carried out in a resistance heating furnace. During melting degasser, borax etc. was used as flux cover into the clay-graphite crucible. The temperature of the melt was always maintained at $780 \pm 15^{\circ} \mathrm{C}$. Then the melt was allowed to be homogenised under stirring at $700^{\circ} \mathrm{C}$ and poured in a mild steel mould size of $17 \times 150 \times 250$ in millimeter. Before pouring the material the mild steel mould was coated inside with a film of water-clay and preheated at $200^{\circ} \mathrm{C}$. The cast samples were first machined to skin out the oxide layer from the surface. All the alloys were analysed by wet chemical analysis and spectroscopy method simultaneously to determine the chemical composition. The chemical compositions of the alloys are given in Table 1.

Tab. 1. Chemical composition of the experimental alloys in weight percent

\begin{tabular}{cccc}
\hline Alloy & $\mathrm{Al}$ & $\mathrm{Al}-\mathrm{Mg}$ & $\mathrm{Al}-\mathrm{Mg}-\mathrm{Zr}$ \\
\hline $\mathrm{Mg}$ & 0.006 & 5.014 & 5.124 \\
\hline $\mathrm{Zr}$ & 0.000 & 0.000 & 0.304 \\
\hline $\mathrm{Si}$ & 0.835 & 0.429 & 0.507 \\
\hline $\mathrm{Fe}$ & 0.627 & 0.375 & 0.269 \\
\hline $\mathrm{Sn}$ & 0.000 & 0.249 & 0.238 \\
\hline $\mathrm{Zn}$ & 0.052 & 0.012 & 0.012 \\
\hline $\mathrm{Ni}$ & 0.000 & 0.007 & 0.008 \\
\hline $\mathrm{Pb}$ & 0.000 & 0.003 & 0.004 \\
\hline $\mathrm{Al}$ & $\mathrm{Bal}$ & $\mathrm{Bal}$ & $\mathrm{Bal}$ \\
\hline
\end{tabular}

Microhardness of the cast test piece of the investigated alloys was measured with a Micro Vickers Hardness Tester. The Knoop indenter was applied with $1000 \mathrm{gm}$ load for $10 \mathrm{~s}$. An average of ten concordant readings was taken as the representative hardness of a sample. Density of the experimental alloys was calculated from the chemical composition of the alloys. Tensile tests was carried out at room temperature in an Instron testing machine using cross head speed to maintain the strain rate of $10^{-3} \mathrm{~s}$. The samples used were according to American Society for Testing and Materials specification [19]. Tensile test was determined using at least five test pieces for each test. The sample of $12 \mathrm{~mm}$ length and $5 \mathrm{~mm}$ diameter were machined from the alloys for wear study by following ASTM G99-05 [20]. The end surface (5 mm diameter) of the pin samples were polished using emery papers $1,0,2 / 0$. Afterwards, the samples were polished in a fine grade wheel polisher. Later, the end surface was cleaned in running water and finally dried in acetone. Hardened mild steel discs were used as the counter-body material. The hardness of the discs was around $\mathrm{RC} 50$. One of the surfaces of the disc was grinded by surface grinding machine and cleaned with cotton. Surface roughness of the disc was $31 \mu \mathrm{m}$. The frictional and wear behaviours of the experimental alloys were investigated in a pin-on disc type wear apparatus by following ASTM Standard G99-05. During the dry wear tests, the end surface of the pin samples were pressed against horizontal rotating mild steel disc. Applied load of $20 \mathrm{~N}$ was used throughout the test, which yielded nominal contact pressures of $1.02 \mathrm{MPa}$. The tests were conducted at the sliding speed of $0.385 \mathrm{~ms}^{-1}$ with varying sliding distances ranging from $116 \mathrm{~m}-2772 \mathrm{~m}$. The tests were carried out in ambient air (relative humidity 60\%) under dry sliding condition. Sets of sample were tested also under in distilled water (wet immersion) and in 3.5\% $\mathrm{NaCl}$ solution (corrosive immersion) at same sliding speed and load against hardened MS disc. At least three tests were done for each type of material. The weight loss difference before and after the test of each samples were taken and wear rates were calculated from average values of weight-loss measurements. Wear rate was estimated by measuring the weight loss $(\triangle W)$ after each test. Care has been given after each test to avoid entrapment of wear debris. The wear rate was calculated using the following expression [21]:

$$
W . R=\frac{\Delta W}{S . D \times L},
$$

where: W.R - wear rate, $\Delta W$ - weight loss, S.D sliding distance, $L-$ load.

Microstructural observation of the worn specimens were done carefully by using OPTIKA Microscope with a CCD camera (Model: OPTIKA) attached to PC imaging at $\times 100$ magnifications and some selected photomicrographs were taken. The SEM investigation 
and EDX analysis were conducted by using Ultra-high resolution JEOL scanning electron microscope with an energy dispersive X-ray analyzer (Model: Link AN 10000) attached.

\section{RESULTS AND DISCUSSION}

\subsection{Physical and Mechanical properties}

Figure 1 and Figure 2 show the physical and mechanical properties of commercially pure Al, $\mathrm{Al}-\mathrm{Mg}$ alloy and $\mathrm{Al}-\mathrm{Mg}-\mathrm{Zr}$ alloy respectively. The density of Al-Mg alloy and $\mathrm{Al}-\mathrm{Mg}-\mathrm{Zr}$ alloy are lower than that of commercially pure $\mathrm{Al}$ because of the presence of approximately $5 \mathrm{wt} \% \mathrm{Mg}$ of quite lower density. A small variation is observed in case of $\mathrm{Al}-\mathrm{Mg}-\mathrm{Zr}$ alloy for the presence of $0.3 \mathrm{wt} \% \mathrm{Zr}$. It is also found that the hardness of pure aluminium increases when $\mathrm{Mg}$ is added to it due to the solid solution hardening. Magnesium has higher specific strength than Aluminium. Thus the addition of $\mathrm{Mg}$ results in increased hardness of alloy as compared to Aluminium [22]. Al-Mg-Zr also shows the highest hardness because of the grain refining effect by $\mathrm{Zr}$ [17].

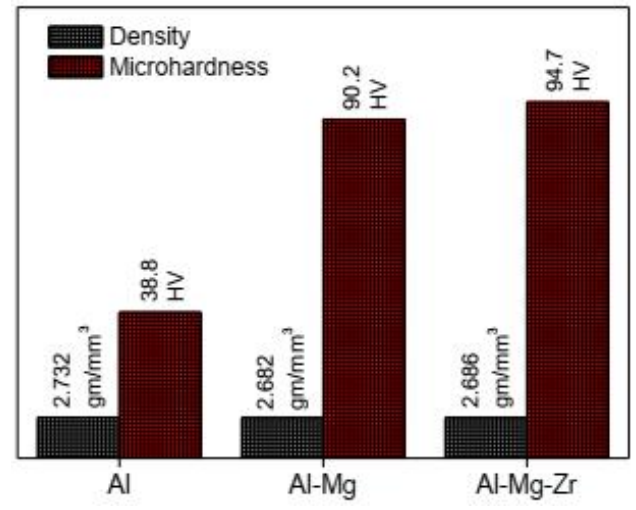

Fig. 1. Density and microhardness of the alloys

It is seen from the Figure 2 that $\mathrm{Mg}$ addition in $\mathrm{Al}$ increases the tensile strength while $\mathrm{Zr}$ addition in $\mathrm{Al}$ $\mathrm{Mg}$ alloy further increases the strength i.e. Al-Mg- $\mathrm{Zr}$ shows the highest strength among the alloys studied. The Al-Mg alloy shows the higher UTS due to the content of higher amount of solute of $\beta^{\prime \prime} \mathrm{L}_{2}\left(\mathrm{Al}_{3} \mathrm{Mg}\right)$ and $\beta^{\prime}$ phase $\mathrm{Al}_{3} \mathrm{Mg}_{2}$, which directly increases mechanical properties of Al-Mg alloys by creating obstacle of dislocation movement occurred under tensile load [23, 24]. In case of Al-Mg-Zr alloy, $\mathrm{Al}_{3} \mathrm{Zr}$ precipitates are formed in the alloy during solidification. The presence of the high number $\mathrm{Al}_{3} \mathrm{Zr}$ contents in the alloys may provides a number of sites for the heterogeneous nucleation of precipitate which yields finer grain structure and results the highest tensile properties of the alloy. It is found that the effect of $\mathrm{Mg}$ and $\mathrm{Zr}$ addition in $\mathrm{Al}$ on the tensile properties is similar to those of hardness. The ductility of $\mathrm{Al}$ is found to decrease with the increase of strength which is obtained due to the addition of $\mathrm{Mg}$ and $\mathrm{Zr}$. $\mathrm{Al}_{3} \mathrm{Mg}$, $\mathrm{Al}_{3} \mathrm{Mg}_{2}$ phases and $\mathrm{Al}_{3} \mathrm{Zr}$ fine precipitates prohibiting the deformation decrease the ductility of $\mathrm{Al}-\mathrm{Mg}$ and Al-Mg-Zr alloy [25, 26].

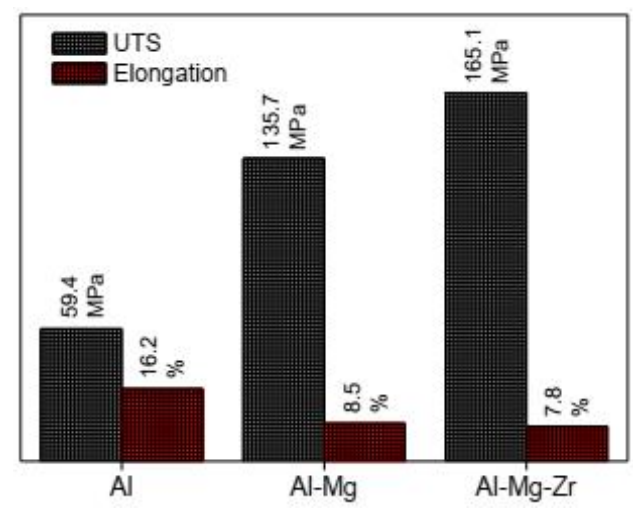

Fig. 2. Tensile properties of the Al alloys

\subsection{Wear behaviour}

Figure 3 elucidate the variation of weight loss with the variation of sliding distance for all the alloys at applied pressure of $1.02 \mathrm{MPa}$ (Normal Load $=20 \mathrm{~N}$ ) in dry sliding environment. It can be seen that, as the sliding distance increases the weight loss increases typically for all the alloys. As sliding distance increases, the contact between rotating disk surface and sliding surface of specimen becomes more familiar with elapse of time which in turn, causes significant increase in weight loss of the alloys. Similar observations have been made by other investees [27, 28].

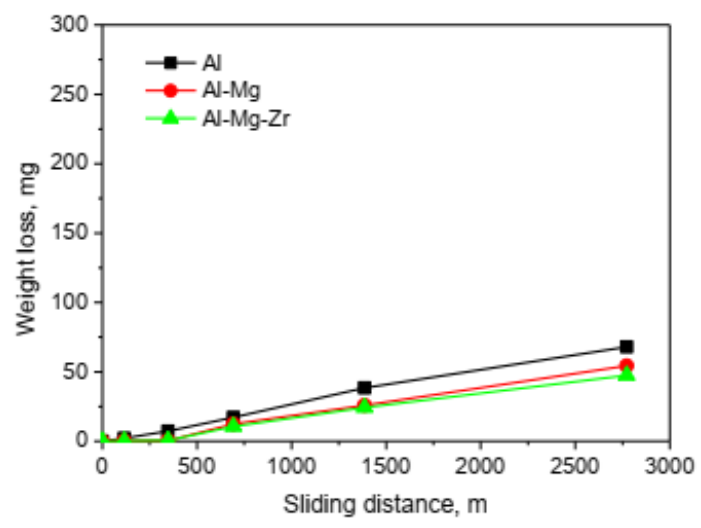

Fig. 3. Variation of weight loss with the sliding distance in dry sliding condition

Moreover, Figures 4-6 elucidate the variation of wear rate with the variation of sliding distance for all the alloys in dry, wet and $3.5 \% \mathrm{NaCl}$ corrosive environment respectively. The wear rate of the alloys in dry sliding condition is found to decrease with the increased hardness of the alloys and this result is found to be consistent with the Archard's theory (Fig. 4) [29]. 
The contact surface of the samples against disc become more conforms to increasing the sliding distance under the abrasive action of hard rotating disc which leads to increase in temperature and the material becomes ductile as well. Al-Mg alloys contains supersaturated amount of magnesium and it forms of the $\beta^{\prime}$ and $\beta$ phases which harden the alloy. It was found that the $\mathrm{Zr}$ addition strengthens the matrix in $\mathrm{Al}-\mathrm{Mg}$ alloy and hence more wear resistance is observed in $\mathrm{Al}-\mathrm{Mg}-\mathrm{Zr}$ alloy as compared to $\mathrm{Al}-\mathrm{Mg}$ alloy. Because, $\mathrm{L}_{2}\left(\mathrm{Al}_{3} \mathrm{Zr}\right)$ phase formed during solidification in Al-Mg-Zr alloy, which are coherent with the matrix and thermally stable [30, 31]. Thus this phase provides high temperature hardness [32].

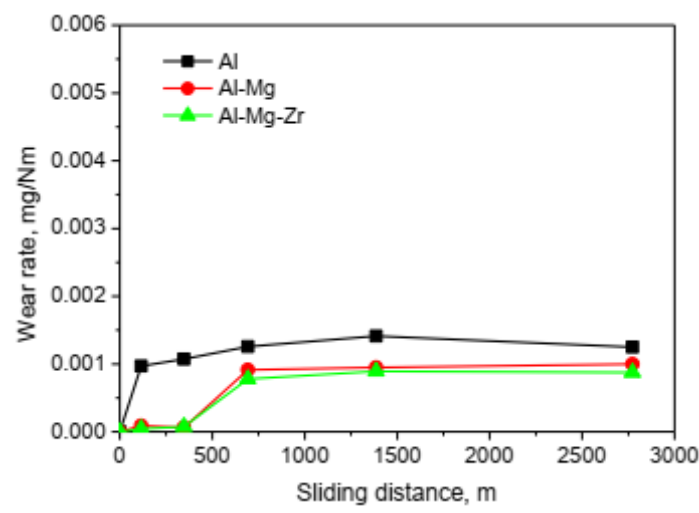

Fig. 4. Variation of wear rate with the sliding distance in dry sliding condition

In case of wet and corrosive environment, the wear rate of $\mathrm{Al}$ is significantly lower than that of $\mathrm{Mg}$ and $\mathrm{Zr}$ added alloys in both conditions (Fig. 7 and Fig. 8). Generally, aluminum shows good corrosion resistance in marine environments because of the formation of a protective adhered aluminum oxide film on the material surface. However, in Al-Mg alloys containing supersaturated amount of magnesium are sensitized with the formation of the $\beta^{\prime}$ and $\beta$ phases which are susceptible to corrosion. Al alloys with more than a 3.5 wt.\% magnesium content become susceptible to the formation of a magnesium-rich $\beta$ intermetallic phase at grain boundaries. Therefore, in a corrosive environment, the $\beta$ phase is preferentially attacked resulting in anodic dissolution of $\beta$ phase from the grain boundaries, which is enhanced under wear action $[33,34]$. It is also observed that the wear rate $\mathrm{Al}-\mathrm{Mg}$ is lower in wet condition than that of $\mathrm{Al}-\mathrm{Mg}-\mathrm{Zr}$ alloy while the rate is found to be higher in $\mathrm{Al}-\mathrm{Mg}$ alloy than the $\mathrm{Al}-\mathrm{Mg}-\mathrm{Zr}$ alloy in corrosive environment. Addition of zirconium improves remarkably stress-corrosion resistance due to formation of subgrains caused by zirconium-bearing particles [35].

The variations of coefficient of friction for commercially pure $\mathrm{Al}, \mathrm{Al}-\mathrm{Mg}$ alloy and $\mathrm{Al}-\mathrm{Mg}-\mathrm{Zr}$ alloy under dry, wet and corrosive condition at different sliding distance have been shown in Figures 7-9 respectively. It is observed that initially the coefficient of friction is low and then increases with increasing sliding distance. Initial low value of frictional coefficient is due to the contact between the oxide layers adhered on the specimen and disc material. Within a short sliding distance, the coefficient of friction raises. Because cracking and removal of surface oxide layer leading to the metal-tometal contact causes an increase in the coefficient of friction. Interface temperature increases with the increment in sliding distance that may promote the surface oxidation and reduce the direct metal contact hence there is slight decline in frictional coefficient [36]. The coefficient of friction for all the alloys in dry environment is much greater than under wet and corrosive environment. The cause of this friction reduction is the "Sealing Effect", which reduces the roughness of the surfaces in contact [37]. In all the cases the coefficient of friction of commercially pure aluminium shows significantly higher than that of $\mathrm{Al}-\mathrm{Mg}$ and $\mathrm{Al}-\mathrm{Mg}-\mathrm{Zr}$ alloys and the result is in good agreement with the observed microhardness value of the alloys. Differences in the extent of localized plastic deformation at real contact areas may lead to the deficiencies in friction coefficient. The $\mathrm{Mg}$ added alloys have exhibited lower friction as they are harder and undergo less plastic deformation [38]. The effects of variation of applied load on friction behavior of the alloys in different sliding condition are shown in Figures 10-12. It is observed that with increase in applied load coefficient of friction increases. This is due to the fact that at higher applied load the amount of deformation or ploughing is more leading to higher coefficient of friction as well as higher wear. It means there is no monotonic trend of variation of wear resistance with applied load probably due to non-homogeneous nature of the material. At higher loads, the oxide debris is expected to get better compacted and mixed and form transfer layer and spread over a larger area of the sliding surface.

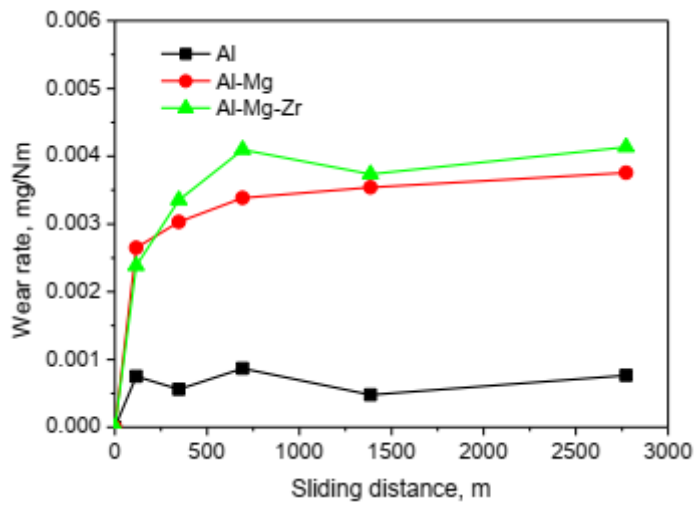

Fig. 5. Variation of wear rate with the sliding distance in wet sliding condition 


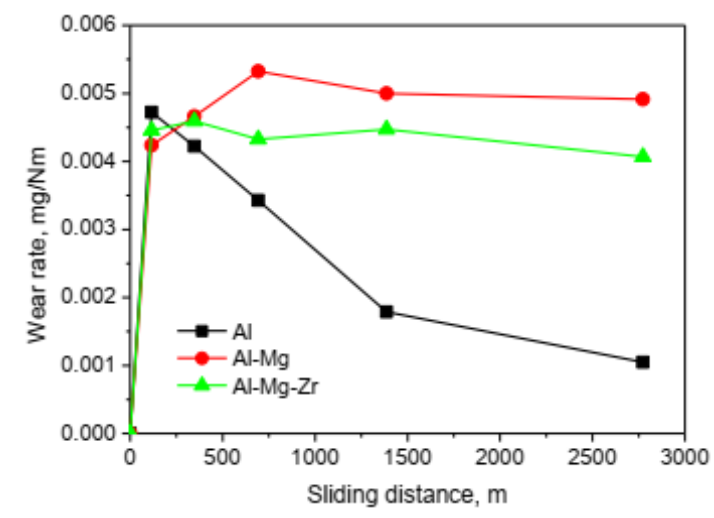

Fig. 6. Variation of wear rate with the sliding distance in corrosive sliding condition

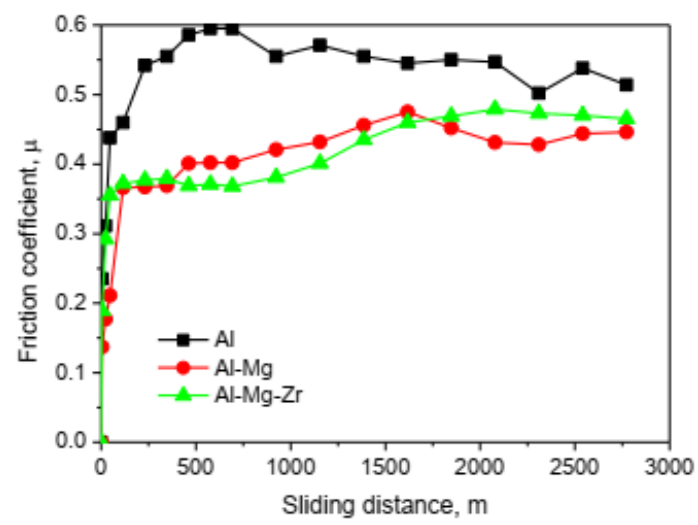

Fig. 7. Variation of friction coefficient with the sliding distance in dry sliding condition

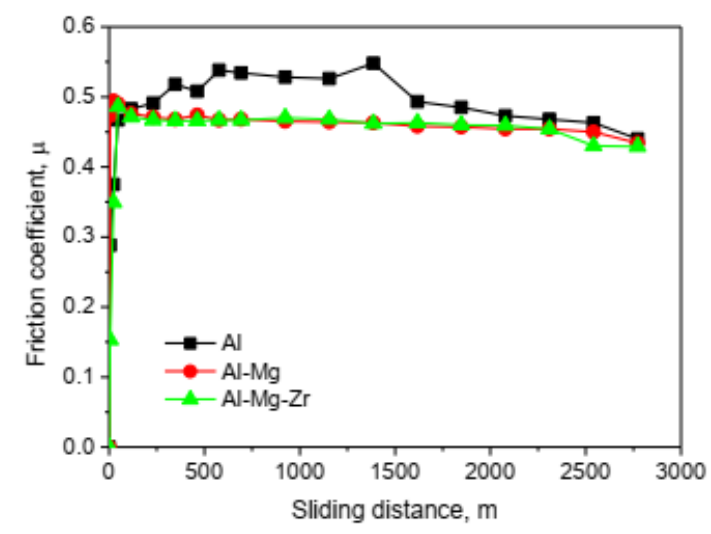

Fig. 8. Variation of friction coefficient with the sliding distance in wet sliding condition

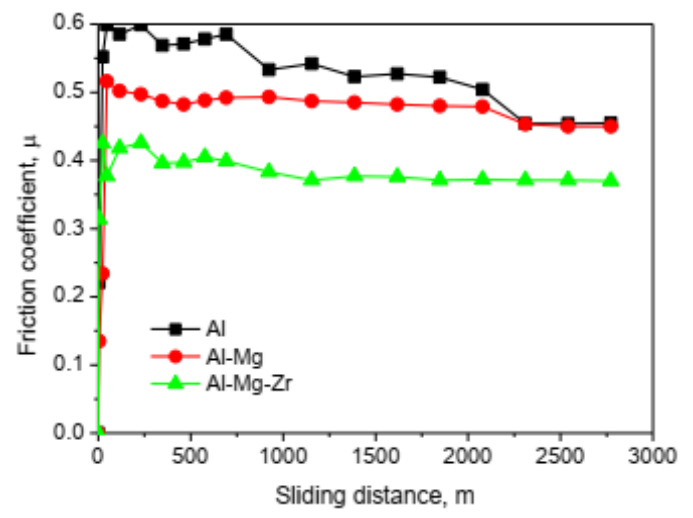

Fig. 9. Variation of friction coefficient with the sliding distance in corrosive sliding condition

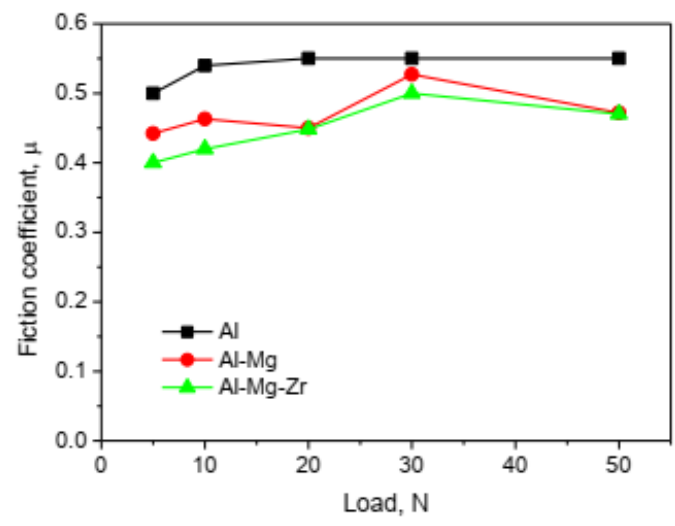

Fig. 10. Variation of friction coefficient with applied load in dry sliding condition

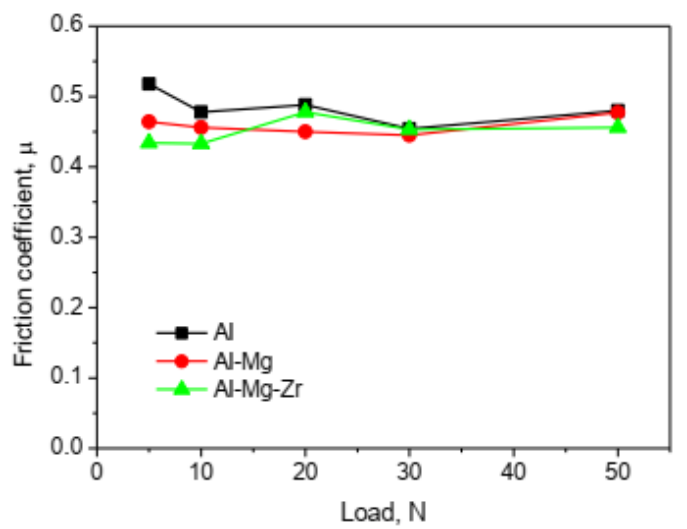

Fig. 11. Variation of friction coefficient with applied load in wet sliding condition 


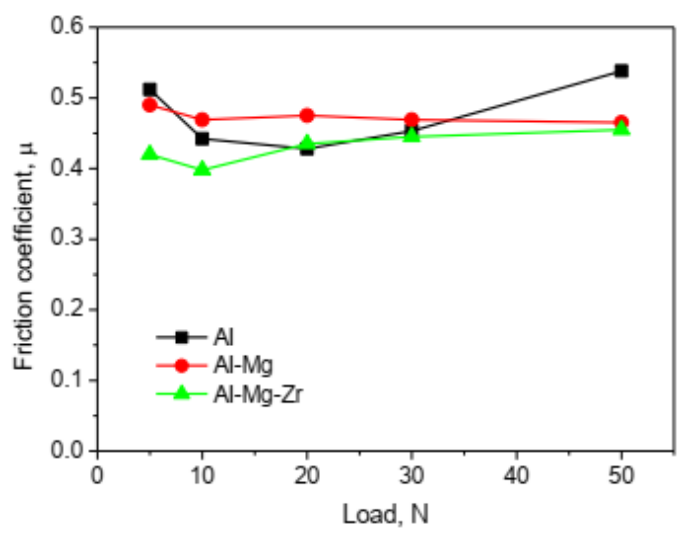

Fig. 12. Variation of friction coefficient with applied load in corrosive sliding condition

However, the wear rate under such circumstances takes place also by flaking of the transfer layer during sliding, apart from the processes of adhesion, microcutting and abrasion. At higher loads, the wearing process could be more aggravated by the transfer layer flaking off as indicated by the presence of a chunky sheet of oxide agglomerates in the wear debris [39]. However, under wet and corrosive condition, the value of coefficient of friction reduced for all the alloys compared with dry condition; this is because of thin lubricating film formation between specimen and rotating disk surface. This thin lubricating film contains lumps of particles and as temperature and normal loads increase these particles break into a small number of particles and reorient themselves along the sliding plane and this leads to lower coefficient of friction [40].

\subsection{Optical microscopic observation}

Figure 13 shows the worn surfaces for all the alloys at different sliding conditions. The optical micrograph of polished alloys have characterized by an Al-rich dendritic matrix, $\alpha$-Al phase and a eutectic mixture in the interdendritic region. In this type of image the precipitates emerge in the dark tone while those of $\alpha$-Al become visible in a lighter tone [41]. From the figure at dry sliding condition, it is observed that crater and small grooves formed at the worn surface due to thermal softening of the material occurred for raising interface temperature at applied loads causing removal of the thin metal layer from the surface which cause the propagation of micro-cracks. From the figure it can also be observed that, at dry condition, the wear marks in the worn surfaces of $\mathrm{Al}-\mathrm{Mg}$ alloy is lofty because of brittle $\beta$-phase, $\mathrm{Al}_{3} \mathrm{Mg}_{2}$, to precipitate in grain boundaries. In case of $\mathrm{Zr}$ added alloy the wear mark relatively reduced because of the presence of $\mathrm{Al}_{3} \mathrm{Zr}$ reinforced particles into the grain. At wet and corrosive environment, wear marks are not clearly visible in the worn surfaces of all the alloys due to the presence of corrosion product. From the figure it can be seen that, Al-Mg alloy showed higher wear corrosion than that of commercially pure Al [42]. No single wear mechanism can be attributed as the rate controlling mechanism throughout the mild wear regime. It was found that low loads and velocities produced sub-microscopic aluminium and iron particle debris which initially detach from the contact surfaces. This mechanically mixed phase predominantly consisted of aluminium oxide. The hardened aluminium oxide then facilitates the detachment of iron from the steel counter-face to produce the iron debris. This debris deposits on the surface and from time to time spall off, contributed to the wear. In case of $\mathrm{Mg}$ added alloy some delaminating layer is observe on the surface because of the stress corrosion cracking initiated by $\beta^{\prime}$ phase $\mathrm{Al}_{3} \mathrm{Mg}_{2}$. On the other hand the wear mark on the $\mathrm{Zr}$ added alloys are uniformly distributed and relative fine due to grain refining effect of the alloys.

\subsection{SEM and EDX observation}

The SEM micrographs of commercially pure Al, $\mathrm{Al}-\mathrm{Mg}$ and $\mathrm{Al}-\mathrm{Mg}-\mathrm{Zr}$ alloy are shown in Figure 14. The commercially pure Al consists of a heterogeneous microstructure with dispersed grains. Because iron and silicon are ever-present impurity elements and the solid solubility of iron in aluminum is very small. Thus phases of aluminum-iron or aluminum-ironsilicon are seen in microstructures (Fig. 14.a). In the as-cast condition, all of the phases that come into equilibrium with aluminum may be found- $\mathrm{FeAl}_{3}$, $\mathrm{Fe}_{3} \mathrm{SiAl}_{12}$, or $\mathrm{Fe}_{2} \mathrm{Si}_{2} \mathrm{Al}_{9}$. In addition, a number of metastable nonequilibrium phases may be formed when solidification is rapid [43, 44]. The corresponding EDX profile analyses for the commercially pure $\mathrm{Al}$ shows the weight percentage of elements as $97.32 \% \mathrm{Al}, 1.73 \% \mathrm{Si}, 0.92 \% \mathrm{Fe}$ and $.03 \%$ $\mathrm{Sn}$. The microstructure of $\mathrm{Al}-\mathrm{Mg}$ alloy shows dendrites with second phase particles within interdendritic spaces (Fig. 14. b) [45]. The silicon particles are also refined due to formation of $\mathrm{Mg}_{2} \mathrm{Si}$ [46]. Addition of $\mathrm{Zr}$ to $\mathrm{Al}-\mathrm{Mg}$ alloy shows a diminution in the amount of second phase particles. It further appears that dendrite arm spacing is decreased in Al$\mathrm{Mg}-\mathrm{Zr}$ alloy with the consequent refinement of dendrites (Fig. 14.c). The dendrites of the cast base alloy are seen to have refined significantly with the addition of $\mathrm{Zr}$. Reportedly alloy with $0.3 \% \mathrm{Zr}$ does not provide much grain refinement but refines the primary dendrites of $\alpha$ with consequent diminution of dendrite arm spacing [47, 48]. The corresponding EDX profile analyses for the Al-Mg alloy the weight percentage of elements found $4.90 \% \mathrm{Mg}, 94.79 \% \mathrm{Al}, 0.19 \% \mathrm{Si}$, $0.08 \% \mathrm{Fe}$ and $0.04 \%$ Sn. Similarly Al-Mg-Zr alloy shows $6.53 \% \mathrm{Mg}, 89.88 \% \mathrm{Al}, 2.79 \% \mathrm{Si}, 0.13 \% \mathrm{Fe}$, $0.57 \% \mathrm{Zr}$ and $0.09 \% \mathrm{Sn}$. 


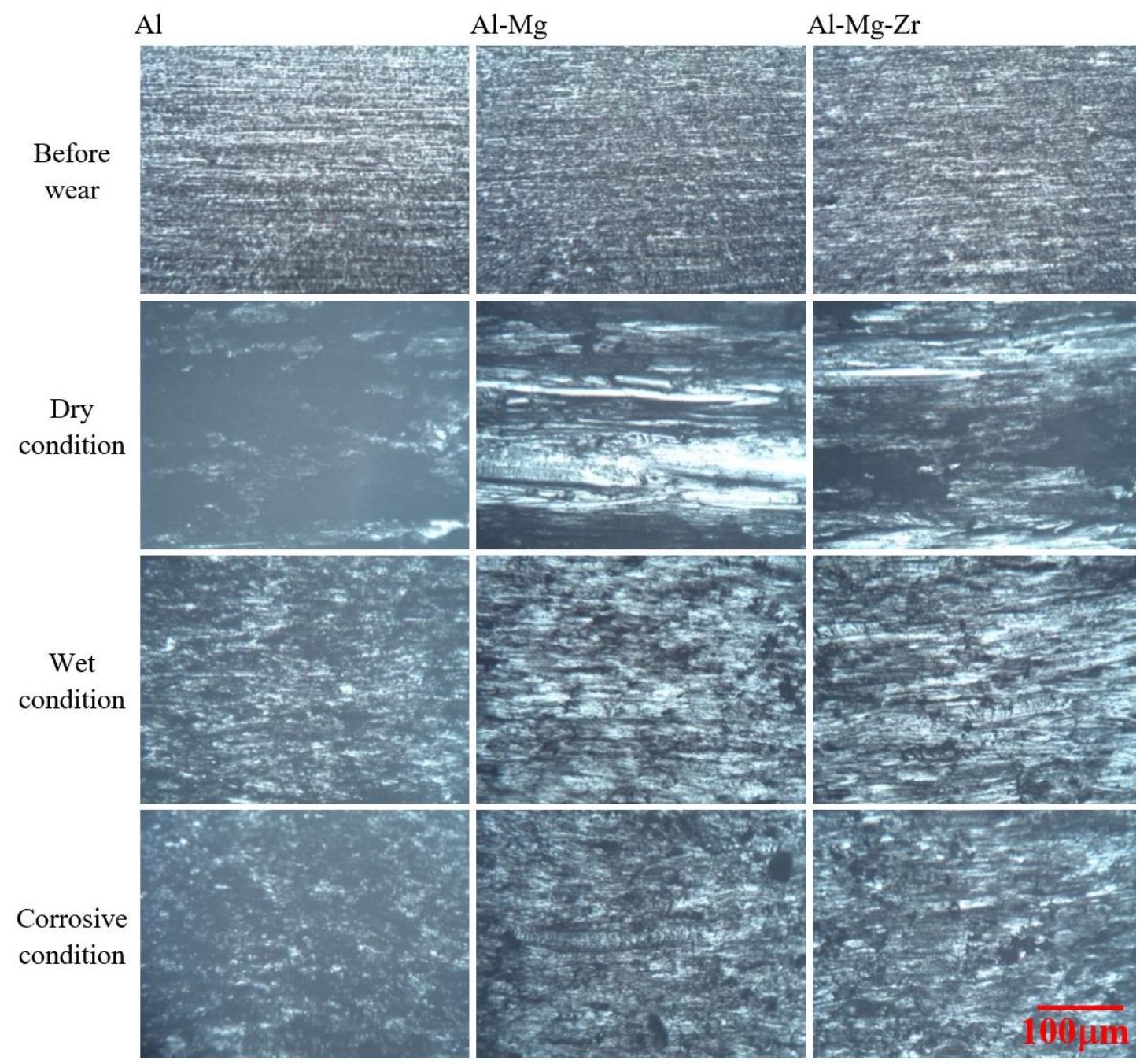

Fig. 13. Optical micrograph of worn surfaces before wear, after wear in dry, wet and corrosive sliding condition

The worn surfaces of the experimental alloys after wear in dry sliding condition are shown in Figure 15 with the help of scanning electron microscope. It is observed that some cracks generated from surface fatigue caused by Hertzian contact stress (Fig. 15. a). On the other hand, some delamination layer is also occurred on the surface of Mg added alloy (Fig. 15. b). The surface of the sample is not only brittle but it is also suitable to plastic yielding. The fracture surface of $\mathrm{Zr}$ added alloy shows the additional brittle surface (Fig. 15 c). Addition of $\mathrm{Mg}$ increases the amount of reinforcing phase $\mathrm{Al} 3 \mathrm{Mg} 2$ which is brittle [49]. When $\mathrm{Zr}$ is added into the alloy, a typical plastic deformation and a large amount of pits are formed into the $\mathrm{Al}-\mathrm{Mg}$ alloys due to presence of fine precipitates of $\mathrm{Al}_{3} \mathrm{Zr}$ as well as grain refining effect $[50,51]$. 
a)

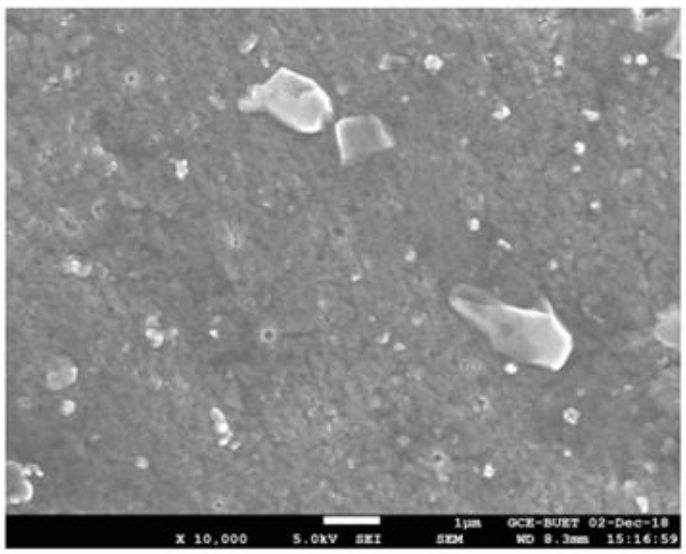

b)

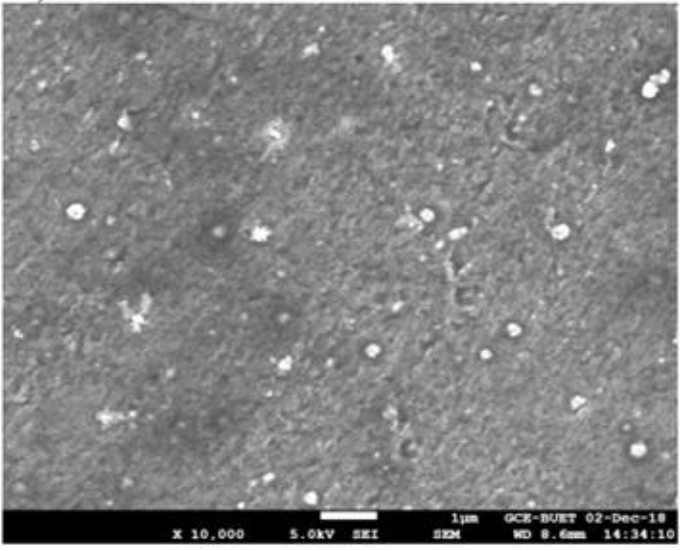

c)

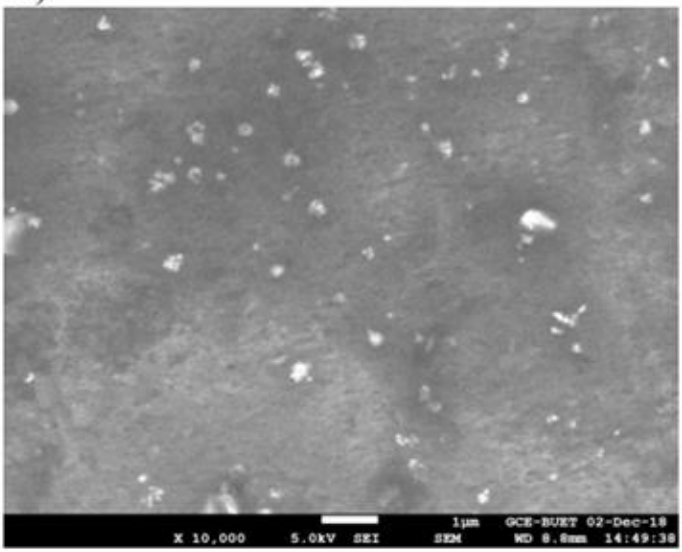

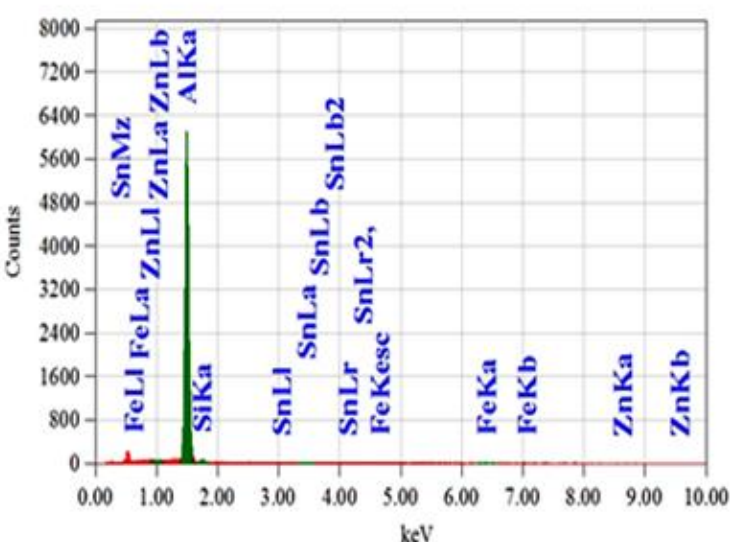
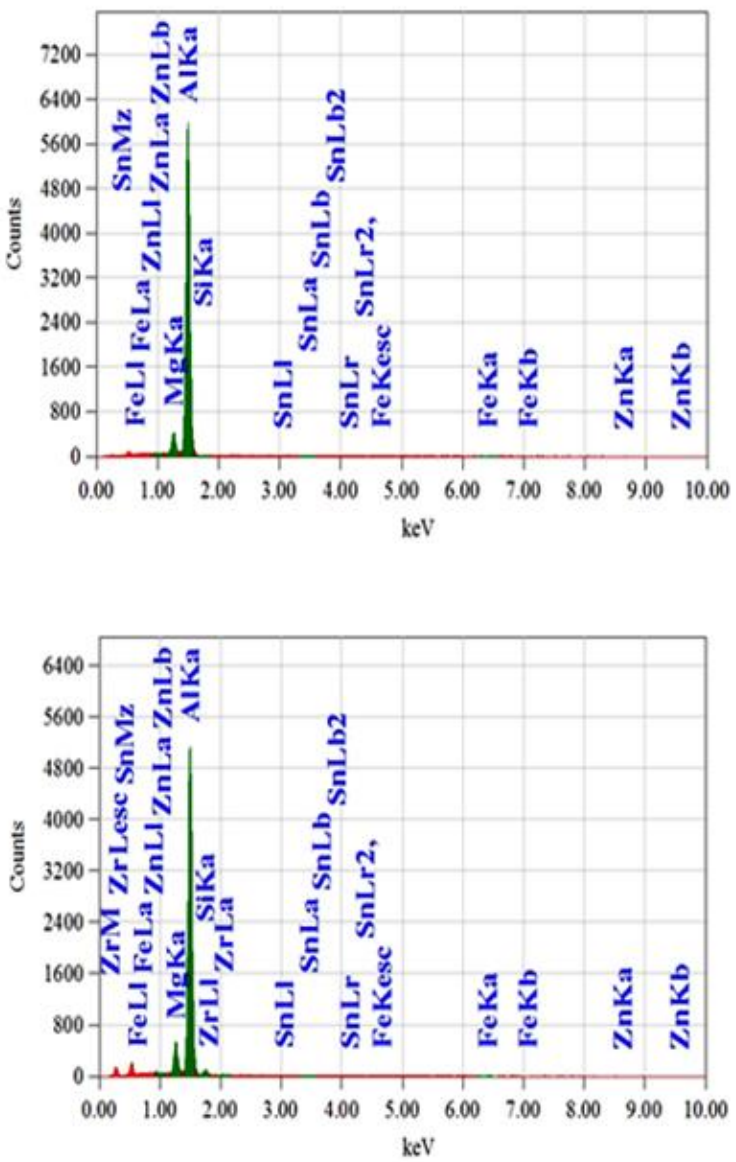

Fig. 14. SEM images and EDX of: a) commercially pure Al, b) Al-Mg alloy, c) Al-Mg-Zr alloy 
a)

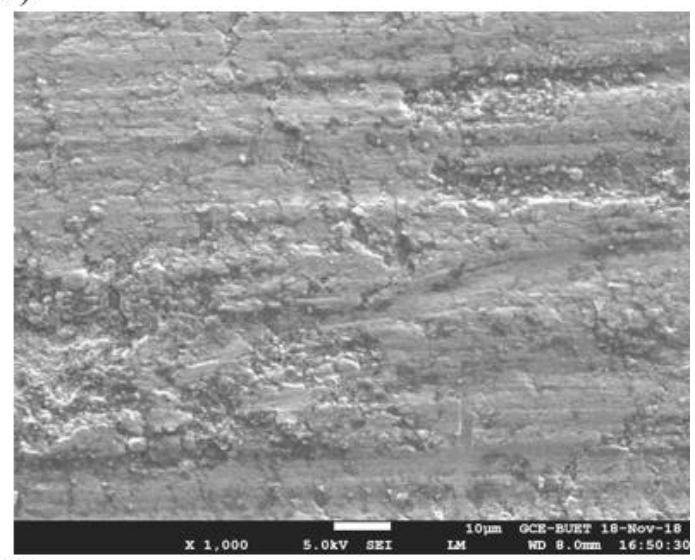

b)

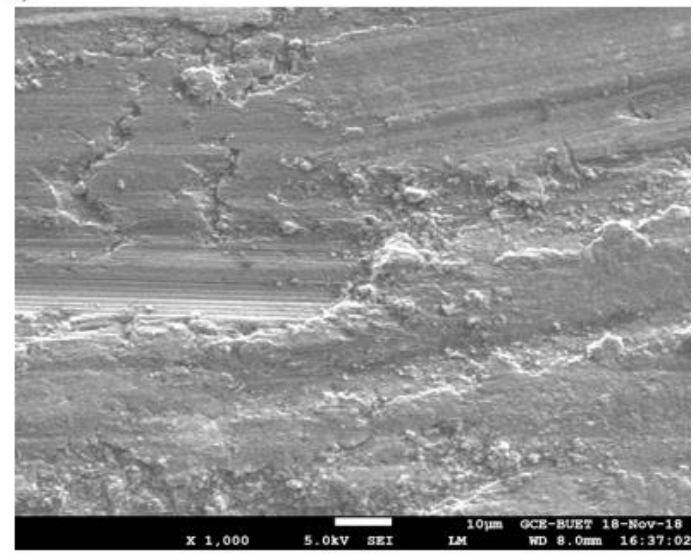

c)

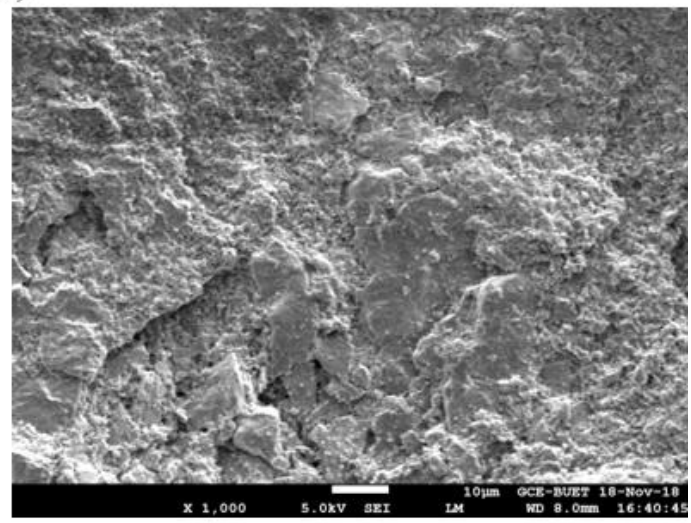

Fig. 15. SEM images of: a) commercially pure Al, b) Al-Mg alloy, c) Al-Mg-Zr alloy after wear in dry sliding condition at 1.02MPa applied pressure and sliding distance of $2772 \mathrm{~m}$

\section{CONCLUSIONS}

In the present work, it was found that the addition of magnesium and zirconium improve the strength of commercially pure aluminium due to the solid solution strengthening and grain refinement effect respectively. It also increases the wear behaviour of the alloys in dry sliding condition. In case of wet and corrosive environment the specimens shows higher amount of material loss i.e. higher wear rate. During this process, magnesium segregates toward the grain boundaries and forms the secondary precipitate $\beta$ phase $\left(\mathrm{Al}_{3} \mathrm{Mg}_{2}\right)$. When exposed to harsh environments such as salt water, a galvanic couple is formed between the $\mathrm{Al}$ matrix and the $\beta$ phase precipitates. The precipitates become anodic to the matrix and preferentially dissolve leaving gaps along the boundary network, ultimately leading to stress corrosion cracking. The coefficient of friction for all the alloys under wet and corrosive environment is lower than dry sliding condition owing to the sealing effect. The wear marks in the worn surfaces of Al-Mg alloy is lofty because of brittle $\beta$-phase precipitate in grain boundaries and the fine fracture grain in case of $\mathrm{Zr}$ added alloy are shown due to grain refining effects.

\section{Acknowledgements}

Thanks to DAERS office of Bangladesh University of Engineering and Technology, Dhaka-1000, for providing the laboratory facilities.

\section{References}

1. Alavudeen A., Venkateshwaran N., Winowlin JT. (2006). A Textbook of Engineering Materials and Metallurgy. Laxmi publications Pvt. Ltd., New Delhi, India.

2. Olabisi AI., Boye TE., Eyere E. (2017). Evaluation of pure aluminium inoculated with varying grain sizes of an agro-waste based inoculant. Advances in Science, Technology and Engineering Systems Journal, Vol. 2, No. 4, pp. 14-25.

3. Polmer IJ. (2005). Light Alloys, from traditional alloys to nanocrystals. 4th edition, Butterworth-Heinemann, UK.

4. Rana RS., Purohit R., Das S. (2012). Reviews on the influences of alloying elements on the microstructure and mechanical properties of aluminum alloys and aluminum alloy composites. International Journal of Scientific and Research Publications, Vol. 2, No. 6, pp. 1-7.

5. Kaiser MS., Banerjee MK. (2008). Effect of ternary scandium and quaternary zirconium and titanium additions on the tensile and precipitation properties of binary cast $\mathrm{Al}-6 \mathrm{Mg}$ alloys. Jordan Journal of Mechanical and Industrial Engineering, Vol. 2, No. 2, pp. 93-99.

6. Krol M., Tanski T., Snopinski P., Tomiczek B. (2017). Structure and properties of aluminium-magnesium casting alloys after heat treatment. Journal of Thermal Analysis and Calorimetry, Vo. 127, No. 1, pp. 299-308.

7. Sanders RE., Hollinshead P., Simielli EA. (2004). Industrial development of non-heat treatable aluminum alloys. Materials Science Forum, Vol. 28, pp. 53-64.

8. Kaiser MS., Datta SA., Roychowdhury A., Banerjee MK. (2008). Effect of scandium on the microstructure and ageing behaviour of cast $\mathrm{Al}-6 \mathrm{Mg}$ alloy. Materials Characterization, Vol. 59, No. 11, pp. 1661-1666.

9. Canales AA., Carrera E., Silva JT., Valtierra S., Colas R. (2012). Mechanical properties in as-cast and heat treated $\mathrm{Al}-\mathrm{Si}-\mathrm{Cu}$ alloys. International Journal of Microstructure and Materials Properties, Vol. 7, No. 4, pp. 281-300.

10. Jayalakshmi S., Dezhi Q., Sankaranarayanan S., Gupta M. (2013). Microstructure and mechanical properties of $\mathrm{Mg}-\mathrm{Al}$ alloys with in situ $\mathrm{Al}_{4} \mathrm{C}_{3}$ phase synthesised by 
$\mathrm{CO}_{2}$ incorporation during liquid state processing. International Journal of Microstructure and Materials Properties, Vol. 8, No. 4/5, pp. 283-98.

11. Kaygisiz Y., Marasli N. (2014). Microstructural, mechanical and electrical characterization of directionally solidified $\mathrm{Al}-\mathrm{Si}-\mathrm{Mg}$ eutectic alloy. Journal of Alloys and Compounds, Vol. 618, pp. 197 203.

12. Shu-Qing Y., Xing-fu L. (2014). The effect of Si morphology on the microstructure and wear property of ZA48 alloy. International Journal of Microstructure and Materials Properties, Vol. 9, No. 1, pp. 88-96.

13. Lin YK., Wang SH., Chen RY., Hsieh TS., Tsai L., Chiang CC. (2017). The effect of heat treatment on the sensitized corrosion of the 5383-H116 Al-Mg Alloy. Materials, Vol. 10, No. 275, pp. 1-9.

14. Kaiser MS. (2014). Fractional recrystallization kinetics in directly cold rolled $\mathrm{Al}-\mathrm{Mg}, \mathrm{Al}-\mathrm{Mg}-\mathrm{Sc}$ and $\mathrm{Al}-\mathrm{Mg}-\mathrm{Sc}-$ $\mathrm{Zr}$ alloy. Iranian Journal of Materials Sciences and Engineering, Vol. 11, No. 4, pp. 80-87.

15. Kendig KL., Miracle DB. (2002). Strengthening mechanisms of an Al-Mg-Sc-Zr alloy. Acta Materialia, Vol. 50, No. 16, pp. 4165-4175.

16. Raghavan V. (2009). Al-Mg-Sc-Ti-Zr (AluminumMagnesium-Scandium-Titanium-Zirconium). Journal of Phase Equilibria and Diffusion, Vol. 30, No. 2, pp. 204-204.

17. Wang F., Eskin DG., Khvan AV., Starodub KF., Lim JJH., Burke MG., Connolley T., Mi J. (2017). On the occurrence of a eutectic-type structure in solidificationof Al-Zr alloys. Scripta Materialia, Vol. 133, pp. 75-78.

18. Kashyap KT. (2001). Effect of zirconium addition on the recrystallization behaviour of a commercial $\mathrm{Al}-\mathrm{Cu}-\mathrm{Mg}$ alloy. Bulletin of Materials Science, Vol. 24, No. 6, pp. 43-648.

19. Davis J.R. (2004). Tensile testing. 2nd edition. ASM International, Materials Park, $\mathrm{OH}$, USA.

20. Filadelfia P. American Society for Testing and Materials (2005). ASTM G99-05: Standard Test Method for Wear Testing with a Pin on Disk Apparatus, ASTM international, West Conshohocken, PA, USA

21. Kaiser MS., Sabbirb SH., Kabir MS., Rahman M., Nur MA. (2018). Study of mechanical and wear behaviour of hyper-eutectic Al-Si automotive alloy through $\mathrm{Fe}, \mathrm{Ni}$ and $\mathrm{Cr}$ addition. Journal of Materials Research, Vol. 21, No. 4, pp. 1-9

22. Behera A., Mishra SC. (2016). Effect of aging on wear behavior of Al-Mg-SiC composite. Journal of Metallurgical and Materials Engineering Research, $\mathrm{Vol}$ 2, No.1, pp. 1-12.

23. Jaafar A., Rahmat A., Zainol I., Hussain Z. (2012). Effects of composition on the mechanical properties and microstructural development of dilute 6000 series alloys. Journal of Applied Sciences, Vol. 12, No. 8, pp. 775-780.

24. Xia S., Ma M., Zhang J., Wang W., Liu W. (2014) Effect of heating rate on the microstructure, texture and tensile properties of continuous cast AA 5083 aluminium alloy. Materials Science and Engineering: A Vol. 609, pp. 168-176.

25. Ebrahimi SHS., Emamy M., Pourkia N., Lashgar HR. (20101). The microstructure, hardness and tensile properties of a new super high strength aluminum alloy with $\mathrm{Zr}$ addition. Materials and Design, vol. 31, pp. 4450-4456.

26. Liang Z., Lin PQ., Bin HY., Zhen WC., Jie LW. (2007). Effect of minor $\mathrm{Sc}$ and $\mathrm{Zr}$ addition on microstructures and mechanical properties of $\mathrm{Al}-\mathrm{Zn}-\mathrm{Mg}-\mathrm{Cu}$ alloys. Trans Nonferrous Met Soc China, Vol. 17, No. 2, pp. 340-345.
27. Hutchings IM. (1994). Tribological properties of metal matrix composites. Materials Science and Technology, Vol. 10, No. 6, pp. 513-517.

28. Ma T., Yamaura H., Koss DA., Voigt RC. (2003). Dry sliding wear behavior of cast SiC-reinforced Al MMCs. Materials Science and Engineering A, Vol. 360, No. 1-2, pp. 116-125.

29. Starink MJ., Zahra AM. (1996). Precipitation kinetics of an Al-15\% Mg alloys studied by microcalorimetry and TEM. Materials Science Forum, Vol. 217-222, pp. $795-800$.

30. Archard JF. (1953). Contact and rubbing of flat surfaces. Journal of Applied Physics, Vol. 24, pp. 981-988.

31. Knipling KE., Dunand DC., Seidman DN., Precipitation evolution in $\mathrm{Al}-\mathrm{Zr}$ and $\mathrm{Al}-\mathrm{Zr}-\mathrm{Ti}$ alloys during aging at $450-600{ }^{\circ} \mathrm{C}$. Acta Materialia, Vol. 56, pp. 118-1195.

32. Kaiser MS. (2018). Efffect of solution treatment on the age hardening behaviour of $\mathrm{Al}-12 \mathrm{Si}-1 \mathrm{Mg}-1 \mathrm{Cu}$ piston alloy with trace $\mathrm{Zr}$ addition. Journal of Casting and Materials Engineering, Vol. 2, No. 2, pp. 30-37.

33. Yasakau KA., Zheludkevich ML., Amaka SV., Ferreira MGS. (2007). Role of intermetallic phases in localized corrosion of AA5083. Electrochimica Acta, Vol. 52, pp. 7651-7659.

34. Liu M., Zanna S., Ardelean H., Frateur I., Schmutz P., Song G., Atrens A., Marcus P. (2009). A first quantitative XPS study of the surface films formed, by exposure to water, on $\mathrm{Mg}$ and on the $\mathrm{Mg}-\mathrm{Al}$ intermetallics: $\mathrm{Al}_{3} \mathrm{Mg}_{2}$ and $\mathrm{Mg}_{17} \mathrm{Al}_{12}$. Corrosion Science, Vol. 51, No. 5, pp. 1115-1127.

35. Yoshida H., Baba Y. (1982). The Role of Zirconium to Improve Strength and Stress-corrosion Resistance of AI$\mathrm{Zn}-\mathrm{Mg}$ and $\mathrm{Al}-\mathrm{Zn}-\mathrm{Mg}-\mathrm{Cu}$ Alloys. Transactions of the Japan Institute of Metals, Vol. 23, No. 10, pp. 620- 630.

36. Dhanasekaran S., Gnanamoorthy R. (2007). Dry sliding friction and wear characteristics of $\mathrm{Fe}-\mathrm{C}-\mathrm{Cu}$ alloy containing molybdenum di sulphide. Materials and Design, Vol. 28, pp. 1135-1141.

37. Meyer WE., Walter JD. (1983). Frictional Interaction of Tire and Pavement, STP 793. American Society for Testing and Materials, USA

38. Nakata K., Kim YG., Fujii H., Tsumura T., Komazaki T. (2005). Improvement of mechanical properties of aluminum die casting alloy by multi-pass friction stir processing. Material Science Engineering, Vol. 437A, pp. 274-279.

39. Tyagi R., Xiong DS., Li J., Dai J. (2011). Effect of load and sliding speed on friction and wear behavior of silver/h-BN containing Ni-base P/M composites. Wear, Vol. 270, No. 7, pp. 423-430.

40. Zmitrowicz A. (2005). Wear debris: A Review of properties and constitutive models. Journal of Theoretical and Applied Mechanics, Vol. 43, No. 1, pp. 3-35.

41. Snopinski P., Tanski T., Labisz K., Rusz S., Jonsta P., Krol M. (2016). Wrought aluminium-magnesium alloys subjected to SPD processing. International Journal of Materials Research, Vol. 107, pp. 1-9.

42. Kaiser S., Kaiser MS. (2020). Wear Behavior of Commercial Pure Copper with $\mathrm{Al}$ and $\mathrm{Zn}$ under Dry, Wet and Corrosive Environment. Journal of Materials and Environmental Sciences, Vol. 11, No. 4, pp. 551-563.

43. Hatch JE. (1984). Aluminium: Properties and Physical Metallurgy. ASM International, Ohio, USA.

44. Sheppard T. (2010). Extrusion of Aluminium Alloys. Springer-Verlag, New York Inc., USA.

45. Kaiser MS. (2014). Effect of Scandium on the Softening Behaviour of Different Degree of Cold Rolled Al-6Mg Alloy Annealed at Different Temperature. International Journal of Advances in Materials Science and Engineering, Vol. 1, No. 1, pp. 39-49. 
46. Gupta AK., Lloyd DJ., Court SA. (2001). Precipitation hardening in $\mathrm{Al}-\mathrm{Mg}-\mathrm{Si}$ alloys with and without excess Si. Materials Science and Engineering A., Vol. 316, No. 1-2, pp. 11-17.

47. Croteau JR., Griffiths S., Rossell MD., Leinenbach C., Kenel C., Jansen V., Seidman DN., Dunand DC., Vo NQ. (2018). Microstructure and mechanical properties of $\mathrm{Al}-\mathrm{Mg}-\mathrm{Zr}$ alloys processed by selective laser melting. Acta Materialia, Vol. 153, pp. 35-44.

48. Liu ZX., Li ZJ., Wang MX., Weng YG. (2008). Effect of complex alloying of $\mathrm{Sc}, \mathrm{Zr}$ and $\mathrm{Ti}$ on the microstructure and mechanical properties of Al-5Mg alloys. Materials Science and Engineering: A., Vol. 483-484, pp. 120-122.

49. Zolriasatein A., Khosroshahi RA., Emamy M., Nemati $\mathrm{N}$., Mechanical and wear properties of $\mathrm{Al}-\mathrm{Al}_{3} \mathrm{Mg}_{2}$ nanocomposites prepared by mechanical milling and hot pressing. International Journal of Minerals, Metallurgy and Materials, Vol. 20, No. 3, pp. 290-297.

50. Kaiser S., Kaiser MS. (2019). Investigation of Mg and Zr Addition on the Mechanical Properties of Commercially Pure Al. International Journal of Mechanical and Materials Engineering, Vol. 13, No. 9, pp. 607-611.

51. Qian H., Zhu D., Hu C., Jiang X. (2018). Effects of Zr additive on microstructure, mechanical properties, and fractography of Al-Si alloy. Metals, Vol. 124, No. 8, pp. $2-10$.

\section{Biographical notes}

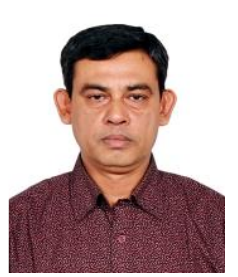

Md. Salim Kaiser was born in Jhenaidah, Bangladesh on November 01, 1962. He received his Graduation degree in Mechanical Engineering from Institution of Engineers, Bangladesh, in 1990, PGD in Industrial Management from Bangladesh Management Development Center, Dhaka, in 1992, the M. Engg. degree in optics from BIT Khulna, Bangladesh, in 2000 and the Ph.D. in Material science from Bengal Engineering and Science University, Shibpur, India, in 2005. He also worked as a post doctoral fellow at the School of Materials Science \& Engineering of that university in 2012. His research interests include materials science, engineering and physics. At present, he is working as Deputy Director, Directorate of Advisory, Extension and Research Services, Bangladesh University of Engineering and Technology, Dhaka. Dr. Kaiser is a fellow of Engineers Institution Bangladesh (IEB) and Bangladesh Computer Society (BCS). He has published more than 100 scientific papers in various international and national journals and conference proceedings.

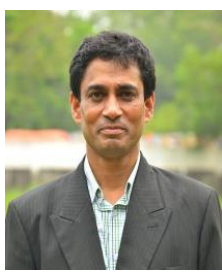

Md. Abdul Matin received his B.Sc. and M.Sc. degree in Materials and Metallurgical Engineering from Bangladesh University of Engineering and Technology, Dhaka in 1995 and 1998 respectively. He obtained his Ph.D. in Materials Science from the department of Mechanical Engineering, Eindhoven University of Technology in 2005. He worked as postdoctoral associate in the reliability and modeling group at IMEC from 2006 to 2007. He then worked as a research fellow in intelligent sensing system research center at Toyohashi University of Technology, Japan from 2007 to 2012. He joined the department of Glass and Ceramic Engineering as an assistant professor in 2012 and was promoted to associate professor in 2017 and professor in 2019 respectively. His research interests include functional thin film materials, photonic glasses, magnetophotonic crystals, multi-scale multi-physics simulations.

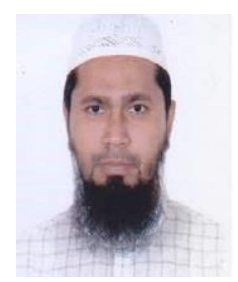

Kazi Md. Shorowordi received his B.Sc., M.Sc. and Ph.D. degree in Materials and Metallurgical Engineering from Bangladesh University of Engineering and Technology, Dhaka in 1995, 1998 and 2005 respectively. He was an International Scholar of the Metallurgy and Materials Engineering Department, Catholic University Leuven, Belgium since November 1998 to April 2001. He worked as a lecturer and assistant professor in the Institute of Appropriate Technology of this University in 2005 and 2006 respectively. He also served as an associate professor in the Materials and Metallurgical Engineering Department where currently he works as a professor of this department. His scientific interests focus on problems concerning heat treatment, material processing and tools as well as tribology. He has published more than 50 scientific papers in various journals. 
